\title{
Characterization of eucalyptus clones subject to wind damage
}

\author{
Antônio José Vinha Zanuncio(1), Amélia Guimarães Carvalho(1), Angélica de Cassia Oliveira Carneiro(1), \\ Paulina Valenzuela(2), William Gacitúa ${ }^{(2)}$, Fernando Palha Leite ${ }^{(3)}$ and Jorge Luiz Colodette(1)
}

\begin{abstract}
(1)Universidade Federal de Viçosa, Departamento de Engenharia Florestal, Avenida Purdue, s/no, Campus Universitário, Edif. Reinaldo de Jesus Araújo, CEP 36570-000 Viçosa, MG, Brazil. E-mail: ajvzanuncio@yahoo.com.br, ameliagcarvalho@gmail.com, cassiacarneiro1@gmail.com, colodett@ufv.br (2)Universidad del Bío-Bío, Departamento de Ingeniería en Maderas, Centro de Biomateriales y Nanotecnología (CBN), 4030000, Concepción, Chile. E-mail: nvalenzu@ubiobio.cl, wgacitua@ubiobio.cl (3)Celulose Nipo-Brasileira S.A. (Cenibra), CEP 35196-000 Belo Oriente, MG, Brazil. E-mail: fernando.leite@cenibra.com.br
\end{abstract}

\begin{abstract}
The objective of this work was to test a new methodology to assess the resistance of trees to wind damage and determine the characteristics that increase clone resistance to winds. Tree resistance to breakage, basic density, ultrastructure, anatomy, mechanical properties, and wood growth stress have been evaluated in seven Eucalyptus grandis $\times$ Eucalyptus urophylla clones, collected from a region with a high incidence of wind damage. The Pearson correlation coefficient between the tree resistance to breakage and the ratio between the area damaged by the winds and the total planted area was -0.839 , showing the efficiency of the methodology adopted and that high breaking strength results in a smaller area affected by wind damage. Trees with a high basic density, cell wall fraction, modulus of elasticity of the middle lamella and fibers, fiber hardness, modulus of rupture, growth stress and low microfibril angle and height and width of the rays showed greater resistance to wind damage. Therefore, the selection of clones with these features may reduce the incidence of damage by winds in Eucalyptus plantations.
\end{abstract}

Index terms: Eucalyptus grandis $\times$ Eucalyptus urophylla, basic density, cell wall fraction, cell wall ultrastructure, fiber, wood.

\section{Caracterização de clones de eucalipto sujeitos a danos provocados pelo vento}

\begin{abstract}
Resumo - O objetivo deste trabalho foi testar uma nova metodologia para avaliar a resistência das árvores aos danos causados pelos ventos e determinar as características que aumentam a resistência dos clones a estes danos. A resistência das árvores à ruptura e a tensão de crescimento, assim como a densidade básica, ultraestrutura, anatomia e propriedades mecânicas da madeira foram avaliadas em sete clones de Eucalyptus grandis $\mathrm{x}$ Eucalyptus urophylla, recolhidos de uma região com uma alta incidência de danos provocados pelo vento. $\mathrm{O}$ coeficiente de correlação de Pearson entre a resistência à ruptura da árvore e a relação entre a área danificada pelos ventos e a área total plantada foi $-0,839$, mostrando a eficiência da metodologia adotada e que alta resistência à quebra resulta em baixa área afetada por danos pelos ventos. Árvores com uma alta densidade básica, fração da parede celular, módulo de elasticidade da lamela média e fibras, dureza da fibra, módulo de ruptura, tensão de crescimento e baixo ângulo microfibrilar e altura e largura dos raios apresentaram maior resistência a danos causados pelo vento. Portanto, a seleção de clones com estas características pode reduzir a incidência de danos causados por ventos em plantações de eucalipto.
\end{abstract}

Termos para indexação: Eucalyptus grandis $\times$ Eucalyptus urophylla, densidade básica, fração de parede celular, ultraestrutura da parede celular, fibra, madeira.

\section{Introduction}

The forestry segment is important for Brazilian economy (IBÁ, 2014). Eucalyptus wood is the main raw material in this industry and can be used to produce pulp, energy, panels, and lumber. In Brazil, the planted forests of Eucalyptus produce an average of $39 \mathrm{~m}^{3} \mathrm{ha}^{-1}$ year ${ }^{-1}$ in a cutting cycle of seven years (IBÁ, 2015). These results are due to climate conditions and investment in research. Despite the favorable outlook, environmental factors, such as wind damages, can limit or restrict the Eucalyptus wood production (Braz et al., 2014; Boschetti et al., 2015).

Wind is a phenomenon that causes disturbances in natural and planted forests, with damage recorded since 1940 (Mitchell, 2013) and reports worldwide (Allen et al., 2012; Mitchell, 2013; Moore et al., 2013). In Brazil, the damage caused by wind in the forest plantations of Eucalyptus spp. occurs mainly between 
24 and 36 months after planting, and depending on the material, this damage can exceed $20 \%$ of the planted area (Braz et al., 2014; Boschetti et al., 2015). The lack of alternatives for this material leads to its use for energy (Guerra et al., 2014).

The winds can bend or break the trees (Mitchell, 2013). In the first case, bending results in the loss of apical dominance (Panshin \& Zeew, 1980), reducing wood production. In the second case, breaking trees affects the entire supply chain, as harvesting trees with smaller diameters reduces the efficiency of this operation and increases costs (Spinelli et al., 2009); in addition, a new cultivation has to be prepared. The trees broken by wind need to be removed from planted forests, thus, it is possible to get this wood for low price, allowing their use in the production of small objects (Vieira et al., 2010) and in the furniture industry (Lopes et al., 2011).

The objective of this work was to test a new methodology for assessing the resistance of trees to breakage, and to evaluate the properties of Eucalyptus wood, relating them to tree resistance to wind damage, and assisting in management of eucalyptus wind damage.

\section{Materials and Methods}

Seven two-year-old Eucalyptus grandis $\times$ Eucalyptus urophylla clones from municipality of Belo Oriente $\left(42^{\circ} 22^{\prime} 30^{\prime \prime} \mathrm{S}, 19^{\circ} 15^{\prime} 00^{\prime \prime} \mathrm{W}\right)$, state of Minas Gerais, Brazil, were selected in February 2014. This region and this Eucalyptus age were chosen because they have a high incidence of wind damage.

Four trees per clone were cut and two discs were removed at 1.3 meter height to evaluate the anatomy, basic density and ultrastructure of the wood, and a three-meter log was removed above these discs for characterization of the wood's mechanical properties. Resistance to breakage and growth stress in trees was conducted in four other trees, per clone. The selected trees had height and diameter evaluated at the height of 1.3-meter, and grew under the same weather conditions and soil. The data of the area broken by the wind and the total planted area were catalogued for each clone (Table 1).

A rope was tied at $85 \%$ of the total height of the tree to evaluate the force required to break the tree in the field. A pulley was attached in a rope between two nearby trees, 12 meters away from each other. The rope tied in the tree to be tested passed through this pulley, forming an angle of approximately $45^{\circ}$. Another pulley was coupled with a dynamometer to measure the force necessary to break the tree. At the end of the rope, a motor was used to pull the tree, according to Braz et al. (2014) (Figure 1).

The force to break the tree and the ratio between the damaged area and the total planted area, per clone, was analyzed by the Pearson correlation coefficient, to assess the quality of the tree resistance test.

The wood basic density was determined as the ratio between the wood dry mass and the wood green volume in one of the $5 \mathrm{~cm}$ discs removed from the tree, at 1.3 meter height, according to standard NBR 11941 (ABNT, 2003).

For anatomical characterization, the sample was obtained from the intermediate position, from pith to bark, from one of the $5 \mathrm{~cm}$ discs removed 1.3 meter above the ground level, for anatomical characterization. Histological sections were made and the macerated material was prepared. The microscopic description of the wood was done according to the International Association of Wood Anatomists - IAWA (Wheeler, 1989). The fiber cell wall thickness was obtained by the difference between the width of the fiber and the lumen diameter, divided by two. The cell wall fraction was calculated according to the following equation (Wheeler, 1989): $\mathrm{CWF}=[(2 \mathrm{CWT}) / \mathrm{FW}] \times 100$, in which: CWT, cell wall thickness $(\mu \mathrm{m})$; FW, fiber width $(\mu \mathrm{m})$; CWF, cell wall fraction (\%).

The microfibril angle (MFA) of the S2 layer was determined in the sample used for anatomical characterization. After saturation, the blocks were cut into $10 \mu \mathrm{m}$ thick sections with a microtome, in the tangential plane, and were macerated with hydrogen peroxide solution and glacial acetic acid in a 2:1 ratio at $55^{\circ} \mathrm{C}$ for 24 hours (Leney, 1981). Next, the fibers were washed in distilled water and temporary slides were prepared to measure the microfibril angle.

The measurement of microfibril angle was performed by polarized light microscopy (Leney, 1981), using an Olympus BX 51 microscope (Olympus Corporation, Shinjuku, Tokyo, Japan) adapted with a rotary stage, graduated from $0^{\circ}$ to $360^{\circ}$, connected to the image analysis program, Image Pro-plus (Media Cybernetics Inc., Rockville, MD, USA). The microfibrillar angle was measured in 30 fibers per sample. The ratio between the basic density and the microfibril angle was calculated according to Hein et al. (2013). 
For a nanoindentation, the sample was removed from the opposite position to that used for anatomical characterization. A $3 \times 3 \times 3 \mathrm{~mm}$ specimen was made from this sample and embedded in epoxy resin solution to determine the modulus of elasticity and hardness of the S2 layer of the fiber and the middle lamella. The nanoindentation was performed using the TriboIndenter Hysitron TI-900®. The maximum applied load was $100 \mu \mathrm{N}$ for 60 seconds, with discharge performed in $20 \mu \mathrm{N} \mathrm{s}^{-1}$ (Muñoz et al., 2012). The elastic modulus was determined according to the equation:

$$
\mathrm{MOE}=\left(1-v \mathrm{~m}^{2}\right) \times\left(\frac{1}{\mathrm{Er}}-\frac{1-v \mathrm{i}^{2}}{\mathrm{Ei}}\right)^{-1}
$$

in which: MOE, modulus of elasticity (GPa); and according to instructions from the device manufacturer, vi, 0.07; vm, 0.35; and Ei, 1,140 GPa. The reduced modulus (Er) was obtained from the load-displacement curve from the initial slope of the unloading wherein the elastic response was generated (Muñoz et al., 2012).

The hardness $(\mathrm{H})$ was determined by the maximum load supported by the specimen divided by the contact area (Muñoz et al., 2012), according to the equation: $\mathrm{H}=\mathrm{Pmax} / \mathrm{A}$ in which: Pmax, maximum load of indenter penetration; A, projected contact areas at maximum load.

A central plank was removed from the three-meter $\log$ removed above 1.3 meter height. With a saw

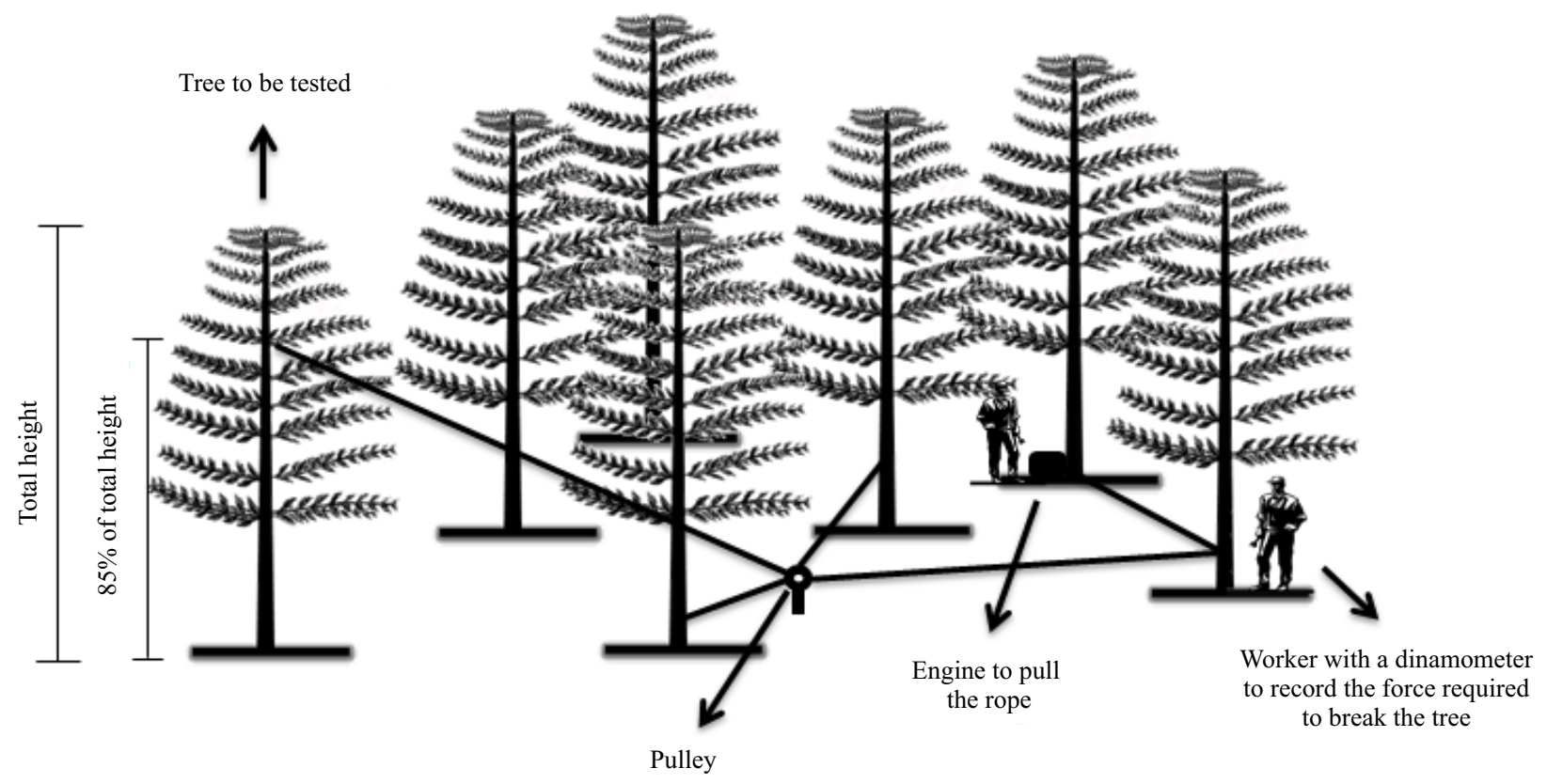

Figure 1. Representation of test for resistance of the trees to breakage.

Table 1. Total planted area, diameter and height average, and average wind broken area for each Eucalyptus grandis $\times$ Eucalyptus urophylla clone from municipality of Belo Oriente, state of Minas Gerais, Brazil.

\begin{tabular}{lccccc}
\hline Clone & $\begin{array}{c}\text { Planted area } \\
(\text { ha) }\end{array}$ & $\begin{array}{c}\text { Diameter at } 1.3 \mathrm{~m} \\
\text { height }(\mathrm{cm})\end{array}$ & $\begin{array}{c}\text { Height } \\
(\mathrm{m})\end{array}$ & $\begin{array}{c}\text { Area broken } \\
\text { by winds (ha) }\end{array}$ & $\begin{array}{c}\text { Area broken by winds per } \\
\text { planted area (\%) }\end{array}$ \\
\hline $\mathrm{A}$ & 2,023 & 10.3 & 15.7 & 237.2 & 16.6 \\
$\mathrm{~B}$ & 1,112 & 11.0 & 15.4 & 1.71 & 1.49 \\
$\mathrm{C}$ & 1,285 & 10.6 & 16.5 & 7.82 & 0.1 \\
$\mathrm{D}$ & 670 & 10.4 & 16.7 & 100.8 & 1.17 \\
$\mathrm{E}$ & 1,684 & 11.3 & 15.6 & 359.6 & 5.98 \\
$\mathrm{~F}$ & 3,638 & 10.8 & 16.6 & 1,603 & 9.89 \\
$\mathrm{G}$ & 10,623 & 10.9 & 17.1 & 15.10 \\
\hline
\end{tabular}


blade, samples were made from the peripheral region of the plank for evaluation of the wood's mechanical properties. The compression parallel to the grain, modulus of elasticity (MOE), and modulus of rupture (MOR) were determined according to American Society for Testing and Materials (ASTM, 1997).

The growth stress was evaluated in the standing trees. The longitudinal displacement (LD) was obtained with the CIRAD's sensor. This method consisted of installing two nails, separated by $45 \mathrm{~mm}$, in the longitudinal direction of the debarked wood (Dassot et al., 2015). Theses nails were connected to a sensor, to record the longitudinal displacement, and a hole was made between these two nails. The longitudinal displacement was recorded and the growth stresses calculated according to Trugilho et al. (2002), using the equation: $\mathrm{GS}=(\mathrm{LD} \times \mathrm{MOE}) / 45$, where: $\mathrm{GS}$, growth stresses; $\mathrm{LD}$, in $\mathrm{mm}$; and $\mathrm{MOE}$, in $\mathrm{MPa}$.

The variance homogeneity analysis (Bartlett's test at $5 \%$ probability) and normality test were performed (Shapiro-Wilk test at $5 \%$ probability). The means of the treatments were compared with the Scott-Knott test at $5 \%$ probability. The Pearson correlation coefficient between the wood properties and the ratio between the damaged and the total area planted, per clone, was generated to assess the characteristics that best related to clone resistance to wind damage.

\section{Results and Discussion}

The area of wind damage per clone varied between 0.1 and $15.1 \%$ of the total planted area, and the force required to break the trees varied between 16.2 and 45.6 kgf (Figure 2). Clones B, C, and D had a smaller area affected by winds and a higher force required to break its trees, resulting in a correlation coefficient between these variables of -0.839 . This value shows that the higher force needed to break the trees results in lower damage area and this technique can be used to evaluate the Eucalyptus clones resistance to wind damage. Braz et al. (2014) reported values between 39.76 and 196.36 kgf to break three-years-old Eucalyptus trees, whose diameter at $1.3 \mathrm{~m}$ height varied between 10.82 and $13.34 \mathrm{~cm}$. This difference occurred due to the age of the trees, because the older ones had larger diameter and greater resistance to breaking.

There was no relationship between the diameter at 1.3 meter height and the area damaged by wind. Trees with larger diameter have greater resistance to this type of phenomenon; however, due to the little variation between the diameters of the evaluated clones, this conclusion does not apply to this work.

There was a relationship between wind damage and: the basic density, microfibril angle, and the ratio between these two parameters (Table 2). Higher basic density resulted in higher wood material per unit volume and greater resistance to breakage (Niklas \&

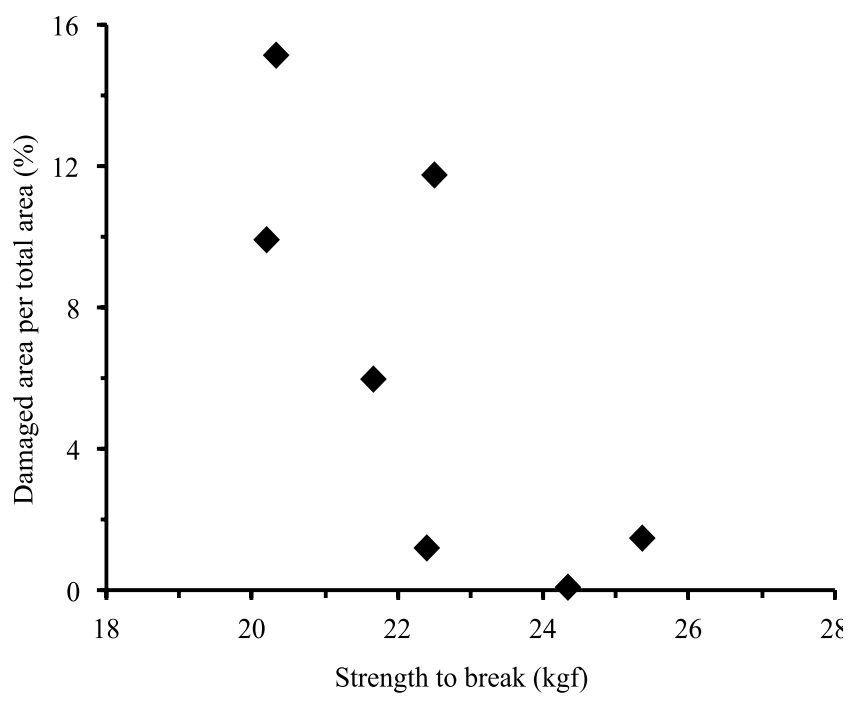

Figure 2. Relationship between the force needed to break the trees and the ratio between damaged area by the winds and total planted area, evaluated in seven two-year-old Eucalyptus grandis $\times$ Eucalyptus urophylla clones from municipality of Belo Oriente, state of Minas Gerais, Brazil.

Table 2. Basic density, microfibril angle and the ratio between these parameters in the seven two-year-old Eucalyptus grandis $\times$ Eucalyptus urophylla clones from municipality of Belo Oriente, state of Minas Gerais, Brazil ${ }^{(1)}$.

\begin{tabular}{lccc}
\hline Clone & $\begin{array}{c}\text { Basic density } \\
\left(\mathrm{g} \mathrm{cm}^{-3}\right)\end{array}$ & $\begin{array}{c}\text { Microfibril } \\
\text { angle }\left({ }^{\circ}\right)\end{array}$ & $\begin{array}{c}\mathrm{Bd} / \mathrm{Ma}^{(2)} \\
\left(\mathrm{g} \mathrm{cm}^{-3} \text { per degree }\right)\end{array}$ \\
\hline $\mathrm{A}$ & $0.372 \mathrm{a}(4.0)$ & $10.40 \mathrm{~b}(8.2)$ & $0.035 \mathrm{a}(8.5)$ \\
$\mathrm{B}$ & $0.423 \mathrm{c}(3.6)$ & $9.16 \mathrm{a}(7.2)$ & $0.046 \mathrm{c}(9.2)$ \\
$\mathrm{C}$ & $0.421 \mathrm{c}(4.1)$ & $9.21 \mathrm{a}(9.8)$ & $0.046 \mathrm{c}(8.3)$ \\
$\mathrm{D}$ & $0.383 \mathrm{a}(3.1)$ & $10.11 \mathrm{~b}(8.5)$ & $0.037 \mathrm{a}(9.7)$ \\
$\mathrm{E}$ & $0.412 \mathrm{~b}(3.1)$ & $10.45 \mathrm{~b}(6.2)$ & $0.040 \mathrm{c}(10.4)$ \\
$\mathrm{F}$ & $0.370 \mathrm{a}(3.9)$ & $9.56 \mathrm{a}(7.5)$ & $0.039 \mathrm{~b}(9.8)$ \\
$\mathrm{G}$ & $0.370 \mathrm{a}(3.5)$ & $10.88 \mathrm{c}(6.6)$ & $0.034 \mathrm{a}(9.3)$ \\
\hline $\mathrm{r}^{(3)}$ & -0.8475 & 0.7089 & -0.869 \\
\hline
\end{tabular}

(1) Means followed by same letter in the column do not differ by the Scott-Knott test at $5 \%$ probability. ${ }^{(2)} \mathrm{Bd} / \mathrm{Ma}$, ratio between basic density and microfibril angle. ${ }^{(3)}$ Pearson correlation coefficient (r) between the variable and the ratio between wind damaged area and the total planted area. Values between parentheses represent the coefficient of variation. 
Spatz, 2012). In addition, a smaller microfibril angle provided a better arrangement of cellulose chains and, therefore, a higher mechanical resistance (Donaldson, 2008). These two features can be summarized in one, as the ratio between the basic density and microfibril angle (Hein et al., 2013), a parameter that showed a better relationship with resistance to winds.

Trees with high basic gravity and low microfibril angle showed greater resistance and, therefore, should be recommended for areas with high incidence of wind damage. The basic density/MFA ratio has the best relationship with the area damaged by the wind, but, for practical purposes, it is possible to use only the basic density to evaluate the resistance of clones to wind, because its determination is quicker and easier than the MFA (Hein et al., 2013).

A high basic density hampers wood processing (Moura et al., 2011) and impregnation of white liquor during the cellulosic pulp manufacturing process, reducing the yield and increasing the rejects (Severo et al., 2013). In general, this parameter increases with age (Wassenberg et al., 2015), so, besides the resistance to wind, the end use of wood should also be considered when selecting clones for areas with a high incidence of wind damage.

All the evaluated anatomical parameters varied between the clones (Table 3). Among the fiber classification parameters, the lumen diameter, cell wall thickness, and cell wall fraction had the highest coefficient of variation. In the evaluation of the histological sections, thehighest values of the coefficient of variation were found for the height and width of the rays, demonstrating the anatomical constituents with higher variation in wood. For the nanoindentation tests, the fibers showed higher values for modulus of elasticity, while the middle lamella had higher hardness values (Table 3). The same tendency was found for the anatomical characteristics in Eucalyptus ssp. (Longui et al., 2014) and nanoindentation tests in Ricinus communis (Li et al., 2014).

Table 3. Anatomical analysis, and modulus of elasticity (MOE) and hardness $(\mathrm{H})$ of the fibers and middle lamella (ML) obtained by nanoindentation of seven two-year-old Eucalyptus grandis $\times$ Eucalyptus urophylla clones from municipality of Belo Oriente, state of Minas Gerais, Brazil ${ }^{(1)}$.

\begin{tabular}{|c|c|c|c|c|c|c|c|c|c|c|c|c|c|}
\hline Clone $^{(2)}$ & $\begin{array}{l}\mathrm{FL}^{(3)} \\
(\mathrm{mm})\end{array}$ & $\begin{array}{l}\mathrm{FW}^{(4)} \\
(\mu \mathrm{m})\end{array}$ & $\begin{array}{l}\mathrm{LD}^{(5)} \\
(\mu \mathrm{m})\end{array}$ & $\begin{array}{c}\mathrm{CWT}^{(6)} \\
(\mu \mathrm{m})\end{array}$ & $\begin{array}{c}\mathrm{CWF}^{(7)} \\
(\%)\end{array}$ & $\begin{array}{c}\text { Vessel } \\
\text { diameter } \\
(\mu \mathrm{m})\end{array}$ & $\begin{array}{c}\text { Vessel freq. } \\
\text { (8) (pores } \\
\left.\mathrm{mm}^{-2}\right)\end{array}$ & $\begin{array}{c}\text { Ray } \\
\text { height } \\
(\mu \mathrm{m})\end{array}$ & $\begin{array}{c}\text { Ray } \\
\text { width } \\
(\mu \mathrm{m})\end{array}$ & $\begin{array}{c}\text { MOE of } \\
\text { S2 layer } \\
(\mathrm{GPa})\end{array}$ & $\begin{array}{c}\text { Hardness } \\
\text { of S2 layer } \\
(\mathrm{GPa})\end{array}$ & $\begin{array}{c}\text { MOE of } \\
\text { ML } \\
(\mathrm{GPa})\end{array}$ & $\begin{array}{c}\text { Hardness } \\
\text { of ML } \\
\text { (GPa) }\end{array}$ \\
\hline A & $0.929 \mathrm{c}$ & $20.05 \mathrm{e}$ & $12.06 \mathrm{c}$ & $3.98 \mathrm{c}$ & $39.71 b$ & $100.1 \mathrm{~b}$ & $10.4 b$ & $217.8 \mathrm{~b}$ & $8.48 d$ & $12.6 b$ & $0.269 \mathrm{a}$ & $7.95 b$ & $0.298 b$ \\
\hline $\mathrm{CV}(\%)$ & 14.6 & 12.1 & 16.4 & 17.1 & 17.2 & 12.4 & 10.8 & 18.3 & 13.5 & 7.1 & 7.3 & 6.9 & 7.0 \\
\hline B & $0.873 b$ & $18.02 \mathrm{~d}$ & $10.18 b$ & $3.92 \mathrm{c}$ & $43.65 \mathrm{c}$ & $113.2 b$ & $8.83 a$ & $226.3 b$ & $6.28 \mathrm{a}$ & $14.1 \mathrm{~b}$ & $0.278 b$ & $8.47 b$ & $0.302 b$ \\
\hline CV $(\%)$ & 14.6 & 12.4 & 16.8 & 17.2 & 16.6 & 13.5 & 12.1 & 16.9 & 15.4 & 7.6 & 7.1 & 7.5 & 7.3 \\
\hline $\mathrm{C}$ & $0.971 d$ & $18.49 \mathrm{~d}$ & $9.77 b$ & $4.36 \mathrm{~d}$ & $47.26 \mathrm{~d}$ & $90.0 \mathrm{a}$ & $10.1 b$ & $239.3 b$ & $6.84 b$ & $15.5 \mathrm{c}$ & $0.289 \mathrm{c}$ & $9.97 \mathrm{c}$ & $0.335 \mathrm{c}$ \\
\hline $\mathrm{CV}(\%)$ & 15.2 & 13.3 & 17.3 & 16.8 & 15.2 & 13.6 & 11.5 & 18.5 & 17.9 & 6.2 & 7.0 & 7.2 & 6.9 \\
\hline D & $0.904 b$ & $16.64 b$ & $9.17 \mathrm{a}$ & $3.73 b$ & $45.07 \mathrm{c}$ & $77.5 \mathrm{a}$ & $14.2 \mathrm{~d}$ & $199.3 \mathrm{a}$ & $7.39 \mathrm{c}$ & $13.2 \mathrm{~b}$ & $0.302 \mathrm{c}$ & $9.61 \mathrm{c}$ & $0.322 \mathrm{c}$ \\
\hline $\mathrm{CV}(\%)$ & 13.7 & 14.5 & 15.9 & 16.5 & 15.2 & 14.2 & 11.5 & 17.4 & 16.3 & 7.1 & 6.8 & 6.9 & 7.2 \\
\hline $\mathrm{E}$ & $0.794 a$ & $15.67 \mathrm{a}$ & $8.90 \mathrm{a}$ & $3.38 \mathrm{a}$ & $43.24 \mathrm{c}$ & $106.6 \mathrm{~b}$ & $13.9 \mathrm{~d}$ & $207.3 a$ & $5.80 \mathrm{a}$ & $13.6 \mathrm{~b}$ & $0.278 \mathrm{~b}$ & $7.15 \mathrm{a}$ & $0.274 \mathrm{a}$ \\
\hline $\mathrm{CV}(\%)$ & 12.8 & 13.4 & 16.4 & 17.3 & 16.2 & 13.2 & 11.8 & 17.8 & 17.5 & 6.3 & 6.6 & 6.8 & 7.2 \\
\hline $\mathrm{F}$ & $0.831 \mathrm{a}$ & $18.76 \mathrm{~d}$ & $11.93 \mathrm{c}$ & $3.41 \mathrm{a}$ & $36.63 a$ & $91.64 \mathrm{a}$ & $12.1 \mathrm{c}$ & $226.3 b$ & $8.53 d$ & $11.0 \mathrm{a}$ & $0.256 \mathrm{a}$ & $6.12 \mathrm{a}$ & $0.301 b$ \\
\hline $\mathrm{CV}(\%)$ & 13.9 & 14.3 & 16.4 & 16.4 & 16.2 & 13.1 & 11.7 & 17.2 & 17.2 & 6.8 & 6.9 & 7.6 & 7.3 \\
\hline G & $0.822 \mathrm{a}$ & $17.62 \mathrm{c}$ & $10.47 b$ & $3.57 b$ & $40.96 \mathrm{~b}$ & $109.6 \mathrm{~b}$ & $11.1 \mathrm{c}$ & $306.4 \mathrm{c}$ & $7.64 \mathrm{c}$ & $11.6 \mathrm{a}$ & $0.266 \mathrm{a}$ & $7.13 \mathrm{a}$ & $0.299 b$ \\
\hline $\mathrm{CV}(\%)$ & 14.7 & 13.2 & 16.6 & 17.3 & 16.3 & 14.5 & 12.5 & 18.1 & 16.8 & 7.0 & 7.3 & 7.2 & 6.8 \\
\hline $\mathrm{r}^{(9)}$ & -0.4637 & 0.3001 & 0.6128 & -0.4817 & -0.7826 & 0.3768 & -0.006 & 0.5724 & 0.5869 & -0.8148 & -0.7861 & -0.7559 & -0.5161 \\
\hline
\end{tabular}

${ }^{(1)}$ Means followed by the same letter in the column do not differ by the Scott-Knott test at $5 \%$ probability. ${ }^{(2)}$ CL, Eucalyptus grandis $\times$ Eucalyptus urophylla clone. ${ }^{(3)} \mathrm{FL}$, fiber length; ${ }^{(4)} \mathrm{FW}$, fiber width. ${ }^{(5)} \mathrm{LD}$, lumen diameter. ${ }^{(6)} \mathrm{CWT}$, cell wall thickness. ${ }^{(7)} \mathrm{CWF}$, cell wall fraction. ${ }^{(8)} \mathrm{Freq} .$, vessel frequency. ${ }^{(9)} \mathrm{r}=$ Pearson correlation coefficient between the variable and the ratio between wind damaged area and the total area planted. CV, coefficient of variation. 
Materials with a lower lumen diameter and higher cell wall thickness corresponded to clones that had smaller damaged area by winds. The fibers have structural function in hardwoods and their morphology influenced the mechanical properties of wood (Slater \& Ennos, 2013). The lumen diameter and cell wall thickness had a different influence on the mechanical properties of wood. These two parameters can be related to one variable, the cell wall fraction, an anatomical variable that had the best relationship with the area damaged by winds, having a Pearson's correlation coefficient of -0.783 .

The vessels conduct water in plants and do not have a structural function. This explains the lack of relationship between this structure and wind damage. The ray cells have thin walls, resulting in low mechanical resistance (Panshin \& Zeew, 1980; Longui et al., 2014), and for this reason, they offer little resistance to wind. This was evidenced by the Pearson correlation coefficient between the height and width of the rays, of 0.572 and 0.587 , respectively, and the area damaged by winds.

Thus, among the anatomical characteristics of the wood, the cell wall fraction showed a better relationship with the resistance of trees to winds and should be considered when selecting clones for areas with high incidence of wind damage.

Higher cell wall fraction and lower microfibril angle resulted in a higher modulus of elasticity of the fiber (Gindl et al., 2004; Borrega \& Gibson, 2015), which increased its resistance to winds. A smaller microfibril angle resulted in a better arrangement of these structures (Hein et al., 2013), which increased the fiber resistance per unit area, and thus, its hardness ( $\mathrm{Li}$ et al., 2014). The middle lamella connects the adjacent cells (Panshin \& Zeew 1980), being important in the tree structure; thus, there was a relationship between the modulus of elasticity of this structure and the resistance to wind damage. Finally, there was no relationship between the hardness of the middle lamella and the resistance to winds.

The mechanical properties of wood and the growth stress of trees showed a relationship with the area of wind damage (Table 4). The modulus of rupture showed a better relationship with the area damaged by the winds per clone, followed by the modulus of elasticity and compression parallel to grain, respectively. The modulus of rupture showed a relationship with the cell wall fraction and basic density (Longui et al., 2014; Dixon et al., 2015), parameters that also showed high correlation with the area damaged by the winds per clone. This showed how wind resistance was the result of a set of wood characteristics.

The Pearson correlation coefficient between the growth stress and the area damaged by winds was -0.625 . Growth stresses result from the internal forces that keep the trees standing (Jullien et al., 2013), being important in areas with wind damage. However, a high growth stress increases the incidence of defects such as cracks and warping, reducing the wood value (Chauhan \& Walker, 2011). Thus, plants with high growth stress are suitable for being planted in areas with high wind damage, but this may compromise wood use for sawmill.

The fact that the clones $\mathrm{B}, \mathrm{C}$, and $\mathrm{D}$ had the smallest area damaged by winds is due to the greater cell wall

Table 4. Compression parallel to grain (CPG), modulus of rupture (MOR), modulus of elasticity (MOE), longitudinal displacement (LD) and growth stress (GS) of the seven two-year-old Eucalyptus grandis $\times$ Eucalyptus urophylla clones from municipality of Belo Oriente, state of Minas Gerais, Brazil ${ }^{(1)}$.

\begin{tabular}{lccccc}
\hline Clone & CPG $(\mathrm{MPa})$ & MOR $(\mathrm{MPa})$ & MOE $(\mathrm{MPa})$ & $\mathrm{LD}(\mathrm{mm})$ & $\mathrm{GS}(\mathrm{MPa})$ \\
\hline $\mathrm{A}$ & $32.9 \mathrm{~b}(10.2)$ & $50.70 \mathrm{~b}(11.3)$ & $5,423 \mathrm{~b}(10.2)$ & $0.099 \mathrm{a}(26.5)$ & $11.79 \mathrm{a}(26.7)$ \\
$\mathrm{B}$ & $34.1 \mathrm{~b}(10.1)$ & $62.76 \mathrm{c}(10.5)$ & $5,643 \mathrm{~b}(11.3)$ & $0.138 \mathrm{~b}(22.4)$ & $17.22 \mathrm{c}(23.6)$ \\
$\mathrm{C}$ & $40.7 \mathrm{~d}(9.5)$ & $74.63 \mathrm{~d}(11.2)$ & $7,038 \mathrm{~d}(12.4)$ & $0.156 \mathrm{c}(23.5)$ & $24.45 \mathrm{~d}(22.5)$ \\
$\mathrm{D}$ & $32.8 \mathrm{~b}(10.9)$ & $59.33 \mathrm{c}(9.5)$ & $5,482 \mathrm{~b}(13.1)$ & $0.116 \mathrm{a}(25.7)$ & $14.15 \mathrm{~b}(27.4)$ \\
$\mathrm{E}$ & $36.1 \mathrm{c}(11.2)$ & $70.22 \mathrm{~d}(10.4)$ & $6,235 \mathrm{c}(9.3)$ & $0.125 \mathrm{~b}(28.9)$ & $17.4 \mathrm{c}(28.3)$ \\
$\mathrm{F}$ & $35.6 \mathrm{c}(10.3)$ & $55.31 \mathrm{~b}(10.7)$ & $5,994 \mathrm{c}(10.5)$ & $0.141 \mathrm{~b}(22.4)$ & $18.3 \mathrm{c}(24.1)$ \\
$\mathrm{G}$ & $33.9 \mathrm{~b}(10.5)$ & $51.78 \mathrm{~b}(9.4)$ & $4,527 \mathrm{a}(11.2)$ & $0.102 \mathrm{a}(27.8)$ & $10.11 \mathrm{a}(22.1)$ \\
\hline $\mathrm{r}^{(2)}$ & -0.4021 & -0.7590 & -0.6525 & -0.6099 & -0.6252 \\
\hline
\end{tabular}

${ }^{(1)}$ Means followed by the same letter in the columns do not differ by the Scott-Knott test at $5 \%$ probability ${ }^{(2)}$ r, Pearson correlation coefficient between the variable and the ratio between wind damaged area and the total area planted. Values between parentheses represent the coefficient of variation. 
fraction of these materials (Table 2). This results in the higher basic density and better mechanical properties of fiber (Vincent et al., 2014) and wood (Slater \& Ennos, 2013) and, with a smaller microfibril angle, improves the resistance of wood to breakage and tree resistance to wind. On account of these characteristics, these materials are more suited for areas with a high incidence of wind damage.

\section{Conclusions}

1. The methodology used is adequate to evaluate the resistance of Eucalyptus clones to winds, with the clones B, C, and D showing lower damaged area and requiring higher force to break its trees.

2. Higher basic density, cell wall fraction, modulus of elasticity of the middle lamella and fibers, fiber hardness, modulus of rupture, growth stress, and lower microfibril angle and height and width of the rays make trees more resistant to breakage, and therefore, are suitable for areas with a high incidence of wind damage.

\section{Acknowledgments}

To Conselho Nacional de Desenvolvimento Científico e Tecnológico (CNPq), to Coordenação de Aperfeiçoamento de Pessoal de Nível Superior (Capes), and to Fundação de Amparo à Pesquisa do Estado de Minas Gerais (Fapemig), for financial support; and to Celulose Nipo-Brasileira S.A., for the support and supply of biological materials.

\section{References}

ABNT. Associação Brasileira de Normas Técnicas. NBR 11941: madeira: determinação da densidade básica. Rio de Janeiro, 2003.

ALLEN, M.S.; THAPA, V.; RAMÓN AREVALO, J.; PALMER, M.W. Windstorm damage and forest recovery: accelerated succession, stand structure, and spatial pattern over 25 years in two Minnesota forests. Plant Ecology, v.213, p.1833-1842, 2012. DOI: $10.1007 / \mathrm{s} 11258-012-0139-9$.

ASTM. American Society for Testing and Materials. D 143-94: Standard test methods for small clear specimens of timber. West Conshohocken, 1997.

BORREGA, M.; GIBSON, L.J. Mechanics of balsa (Ochroma pyramidale) wood. Mechanics of Materials, v.84, p.75-90, 2015. DOI: 10.1016/j.mechmat.2015.01.014.

BOSCHETTI, W.T.N.; PAES, J.B.; OLIVEIRA, J.T.S.; DUDECKI, L. Características anatômicas para produção de celulose do lenho de reação de árvores inclinadas de eucalipto. Pesquisa Agropecuária Brasileira, v.50, p.459-467, 2015. DOI: 10.1590/S0100-204X2015000600004.

BRAZ, R.L.; OLIVEIRA, J.T. da S.; ROSADO, A.M.; VIDAURRE, G.B.; PAES, J.B. Parâmetros dendrométricos e resistência mecânica das árvores de clones de Eucalyptus em áreas sujeitas à ação dos ventos. Ciência Florestal, v.24, p.947-958, 2014. DOI: $10.5902 / 1980509816608$.

CHAUHAN, S.S.; WALKER, J.C.F. Wood quality in artificially inclined 1-year-old trees of Eucalyptus regnans - differences in tension wood and opposite wood properties. Canadian Journal of Forest Research, v.41, p.930-937, 2011. DOI: 10.1139/x11-016.

DASSOT, M.; CONSTANT, T.; NINGRE, F.; FOURNIER, M. Impact of stand density on tree morphology and growth stresses in young beech (Fagus sylvatica L.) stands. Trees, v.29, p.583-591, 2015. DOI: $10.1007 / \mathrm{s} 00468-014-1137-4$.

DIXON, P.G.; AHVENAINEN, P.; AIJAZI, A.N.; CHEN, S.H.; LIN, S.; AUGUSCIAK, P.K.; BORREGA, M.; SVEDSTRÖM, K.; GIBSON, L.J. Comparison of the structure and flexural properties of Moso, Guadua and Tre Gai bamboo. Construction and Building Materials, v.90, p.11-17, 2015. DOI: 10.1016/j. conbuildmat.2015.04.042.

DONALDSON, L. Microfibril angle: measurement, variation and relationships: a review. IAWA Journal, v.29, p.345-386, 2008. DOI: $10.1163 / 22941932-90000192$.

GINDL, W.; GUPTA, H.S.; SCHÖBERL, T.; LICHTENEGGER, H.C.; FRATZL, P. Mechanical properties of spruce wood cell walls by nanoindentation. Applied Physics A, v.79, p.2069-2073, 2004. DOI: $10.1007 / \mathrm{s} 00339-004-2864-y$.

GUERRA, S.P.S.; GARCIA, E.A.; LANCAS, K.P.; REZENDE, M.A. de; SPINELLI, R. Heating value of eucalypt wood grown on SRC for energy production. Fuel, v.137, p.360-363, 2014. DOI: 10.1016/j.fuel.2014.07.103.

HEIN, P.R.G.; SILVA, J.R.M.; BRANCHERIAU, L. Correlations among microfibril angle, density, modulus of elasticity, modulus of rupture and shrinkage in 6-year-old Eucalyptus urophylla $\times E$. grandis. Maderas. Ciencia y Tecnología, v.15, p.171-182, 2013. DOI: $10.4067 /$ S0718-221X2013005000014.

IBÁ. Indústria Brasileira de Árvores. IBÁ 2014. 2014. Available at: $<$ http://www.bracelpa.org.br/shared/iba_2014_pt.pdf $>$. Accessed on: Oct. 122016

IBÁ. Indústria Brasileira de Árvores. Relatório IBÁ 2015. [Brasília], 2015. 79p. Available at: <http:/www.iba.org/images/ shared/iba_2015.pdf $>$. Accessed on: Oct. 122016.

JULLIEN, D.; WIDMANN, R.; LOUP, C.; THIBAUT, B. Relationship between tree morphology and growth stress in mature European beech stands. Annals of Forest Science, v.70, p.133142, 2013. DOI: 10.1007/s13595-012-0247-7.

LENEY, L. A technique for measuring fibril angle using polarized light. Wood and Fiber Science, v.13, p.13-16, 1981.

LI, X.; DU, G.; WANG, S.; YU, G. Physical and mechanical characterization of fiber cell wall in castor (Ricinus communis L.) stalk. BioResources, v.9, p.1596-1605, 2014. DOI: 10.15376/ biores.9.1.1596-1605. 
LONGUI, E.L.; ROMEIRO, D.; PFLEGER, P.; LIMA, I.L.; SILVA JR., F.G.; GARCIA, J.N.; BORTOLETTO JR., G.; FREIRE NETO, A.O.L.; FLORSHEIM, S.M.B. Radial variation of anatomical features, physicomechanical properties and chemical constituents and their potential influence on the wood quality of 45-year-old Eucalyptus propinqua. Australian Forestry, v.77, p.78-85, 2014. DOI: $10.1080 / 00049158.2014 .905739$.

LOPES, C.S.D.; NOLASCO, A.M.; TOMAZELLO FILHO, M.; DIAS, C.T. dos S.; PANSINI, A. Estudo da massa específica básica e da variação dimensional da madeira de três espécies de eucalipto para a indústria moveleira. Ciência Florestal, v.21, p.315-322, 2011.

MITCHELL. S.J. Wind as a natural disturbance agent in forests: a synthesis. Forestry, v.86, p.147-157, 2013. DOI: 10.1093/forestry/ $\operatorname{cps} 058$.

MOORE, J.R.; MANLEY, B.R.; PARK, D.; SCARROTT, C.J. Quantification of wind damage to New Zealand's planted forests. Forestry, v.86, p.173-183, 2013. DOI: 10.1093/forestry/cps076.

MOURA, L.F. de; BRITO, J.O.; NOLASCO, A.M.; ULIANA, L.R. Effect of thermal rectification on machinability of Eucalyptus grandis and Pinus caribaea var. hondurensis woods. European Journal of Wood and Wood Products, v.69, p.641-648, 2011. DOI: $10.1007 / \mathrm{s} 00107-010-0507-\mathrm{x}$.

MUÑOZ, F.; VALENZUELA, P.; GACITÚA, W. Eucalyptus nitens: nanomechanical properties of bark and wood fibers. Applied Physics A, v.108, p.1007-1014, 2012. DOI: 10.1007/ s00339-012-7014-3.

NIKLAS, K.J.; SPATZ, H.-C. Mechanical properties of wood disproportionately increase with increasing density. American Journal of Botany, v.99, p.169-170, 2012. DOI: 10.3732/ ajb.1100567.

PANSHIN, A.J.; ZEEUW, C. de. Textbook of wood technology. New York: Michigan State University, 1980. 722p.
SEVERO, E.T.D.; SANSÍGOLO, C.A.; CALONEGO, F.W.; BARREIROS, R.M. Kraft pulp from juvenile and mature woods of Corymbia citriodora. BioResources, v.8, p.1657-1664, 2013. DOI: $10.15376 /$ biores.8.2.1657-1664.

SLATER, D.; ENNOS, A.R. Determining the mechanical properties of hazel forks by testing their component parts. Trees, v.27, p.1515-1524, 2013. DOI: 10.1007/s00468-013-0898-5.

SPINELLI, R.; WARD, S.M.; OWENDE, P.M. A harvest and transport cost model for Eucalyptus spp. fast-growing short rotation plantations. Biomass and Bioenergy, v.33, p.1265-1270, 2009. DOI: 10.1016/j.biombioe.2009.05.010.

TRUGILHO, P.F.; LIMA, J.T.; ROSADO, S.C. da S.; MENDES, L.M.; MORI, F.A.; SOUZA, M.A.M. de. Avaliação da tensão de crescimento em clones de Eucalyptus. Floresta e Ambiente, v.9, p.38-44, 2002.

VIEIRA, R. da S.; LIMA, J.T.; SILVA, J.R.M. da; HEIN, P.R.G.; BAILLÈRES, H.; BARAÚNA, E.E.P. Small wooden objects using eucalypt sawmill wood waste. BioResources, v.5, p.1463$1472,2010$.

VINCENT, M.; TONG, Q.; TERZIEV, N.; DANIEL, G.; BUSTOS, C.; ESCOBAR, W.G.; DUCHESNE, I. A comparison of nanoindentation cell wall hardness and Brinell wood hardness in jack pine (Pinus banksiana Lamb.). Wood Science and Technology, v.48, p.7-22, 2014. DOI: 10.1007/s00226-013-0580-5.

WASSENBERG, M.; CHIU, H.-S.; GUO, W.; SPIECKER, H. Analysis of wood density profiles of tree stems: incorporating vertical variations to optimize wood sampling strategies for density and biomass estimations. Trees, v.29, p.551-561, 2015. DOI: $10.1007 / \mathrm{s} 00468-014-1134-7$.

WHEELER, E.; BAAS, P.; GASSON, P.E. (Ed.). IAWA list of microscopic features for hardwood identification. Leiden: IAWA, 1989. (IAWA Bulletin n.s., 10).

$\overline{\text { Received on October 12, } 2016 \text { and accepted on April 13, } 2017}$

Pesq. agropec. bras., Brasília, v.52, n.11, p.969-976, nov. 2017

DOI: $10.1590 / \mathrm{S} 0100-204 \mathrm{X} 2017001100002$ 